\title{
SERUM PROTEINS AND BLOOD ALPHA AMINO NITROGEN IN CEREBRAL PALSY
}

\author{
BY \\ DAVID BURMAN* AND R. R. REMBOLT \\ From the Hospital School for Handicapped Children, State University of Iowa, U.S.A.
}

(RECEIVED FOR PUBLICATION MAY 2, 1960)

\begin{abstract}
The mean serum proteins of 30 children over the age of 3 suffering from cerebral palsy was 7.20 with a standard deviation of $0.49 \mathrm{~g}$. per $100 \mathrm{ml}$. No difference was found between children with the spastic and athetoid types of cerebral palsy. The electrophoretic pattern of the serum proteins did not differ in the two types, but the alpha 2 globulin diminished significantly with increasing age. There was no difference that could be considered "clinically significant" between the total serum proteins or their electrophoretic pattern in children with cerebral palsy and in four published series of normal children.

The plasma and whole blood alpha amino nitrogen showed no significant difference between the two types of cerebral palsy.
\end{abstract}

Because there does not appear to be any information about serum proteins in children with cerebral palsy in the literature, the total serum proteins and their electrophoretic pattern in children over 3 years of age with athetoid and spastic types of cerebral palsy were determined. The results in the athetoid and spastic children were compared with each other and with published data in normal children.

\section{Methods}

Thirty children ( 15 boys and 15 girls) were studied between the ages of 3 and 19 years. All the children had been in-patients in this hospital school for at least one month and had been free from infection during this time. The children had all been immunized against diphtheria, pertussis, tetanus, and whooping cough, and had been vaccinated. All blood specimens were taken by venepuncture throughout a four-week period in November and December, 1958. The serum was separated immediately after the clot had retracted and was then stored frozen until the protein estimations were performed. Blood samples for the alpha amino nitrogen determinations were collected in tubes containing dried heparin, but three were haemolysed and discarded. No attempt was made to ensure that blood was drawn in the fasting state since no difference has been found between serum proteins before and after meals (Trevorrow, Kaser, Patterson, and Hill, 1942; Oberman, Gregory, Burke, Ross, and Rice, 1956).

The concentration of protein nitrogen was calculated by the difference between total nitrogen and non-protein nitrogen. The observed nitrogen concentrations were determined by micro-Kjeldahl digestion (Van Slyke and Kugel, 1933) and microdiffusion (Conway and O'Malley,

* Present address: St. Mary's Hospital, London, W.C.2.
1942). The total serum proteins were calculated by multiplying the protein nitrogen by 6.25 .

The method and apparatus used for filter paper electrophoresis were exactly those described in the instruction manual RIM-5 for the " spinco " model R paper electrophoresis system published by Beckman, California, with the exception that the voltage was kept constant at 80 volts and the division of the components was made by dropping a vertical from the intersection of the Gaussian distribution curves.

The alpha amino nitrogen levels in plasma and whole blood were estimated by the ninhydrin method of Yemm and Cocking (1955) after precipitation of the plasma proteins and haemoglobin with trichloroacetic acid.

\section{Results}

The results in the two groups of children with cerebral palsy are tabulated in Table I. There is no significant difference at the $5 \%$ level between the means or variances of any of these blood constituents. Similarly there are no significant differences in the variances or means between children of different sexes.

Pearsonian correlation coefficients were estimated between age and each of the blood constituents in Table I. The only significant findings were a negative correlation between age and alpha 2 globulin percentage $(r=-0.3818 ; 0.05>P>0.02)$. The correlation between age and the absolute concentration of alpha 2 globulin was not significant $(r=-0.2179 ; 0.20>P=0.10)$.

In order to make the results comparable, the normal series in Table II were recalculated to eliminate children under 3 years old and to correct 
TABLE I

COMPARISON OF SERUM PROTEINS AND BLOOD ALPHA AMINO NITROGEN LEVELS IN CHILDREN WITH ATHETOID AND SPASTIC TYPES OF CEREBRAL PALSY

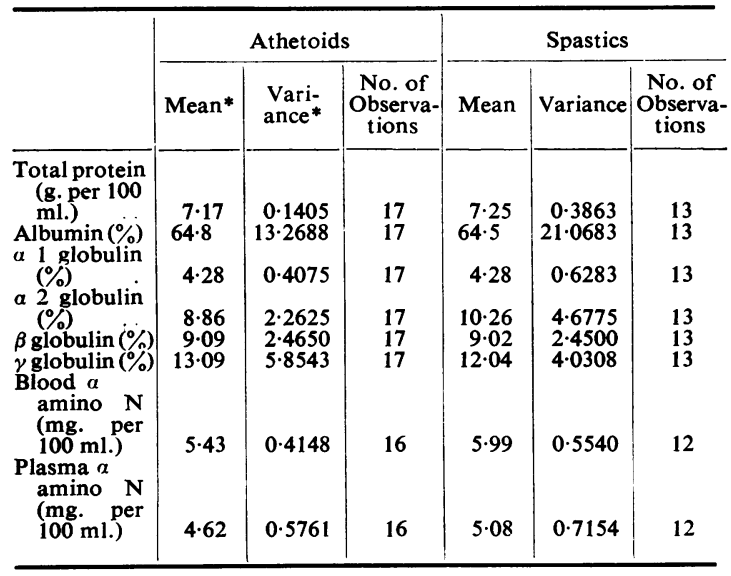

*There is no significant difference between the means or variances of any of these blood constituents in the two groups of children.

plasma levels to serum levels by eliminating the difference due to fibrinogen. Because no difference was found between spastics and athetoids, all our observations are considered in one group in Table II.

\section{Discussion}

The present observations on the serum proteins, their electrophoretic patterns, and the blood alpha amino nitrogen have been performed under particularly standardized conditions. The children were all resident in the same hospital school and were offered the same diet. They had all received the same immunization programme and had been known to be free of infection for at least one month. The specimens were all taken in the same month, thus eliminating the seasonal differences in the serum albumin found by Trevorrow and her colleagues (1942). All the estimations were made in the same laboratories with the same apparatus and by the same technicians within a period of three months. The children differ by age, sex, and diagnosis. Sex and diagnosis have already been shown to make no significant difference to any of these constituents of blood.

Only children over the age of 3 years were studied, partly because it is often difficult to be certain of the type of cerebral palsy earlier. The total serum proteins, wiich va'y in infancy, reach adult levels at about 3 years (Trevo 1 ow and others, 1942), and on electrophoretic studies there are only minor changes in the various fractions after this age (Knapp and Routh. 1949). The only significant change with an increasing age discovered in this series was a fall in the proportion of alpha 2 globulin but not its absolute amount. Knapp and Routh (1949) also noted the fall in the proportion of alpha 2 globulin with rising age but they analysed their results be considering arbitrary age groups. Their results ib. children 3 to 17 years old were corrected for the presence of fibrinogen and the correlation coefficient ( $\mathrm{r}=-0.2924)$ with age was found to be significant at the $10 \%$ level but not at the $5 \%$ level. Lubschez

TABLE II

COMPARISON OF TOTAL SERUM PROTEINS AND THEIR ELECTROPHORETIC PATTERN OF 30 CHILDREN WITH CEREBRAL PALSY WITH PUBLISHED SERIES OF NORMAL CHILDREN*

\begin{tabular}{|c|c|c|c|c|c|c|c|c|c|c|}
\hline \multirow{2}{*}{ Source } & \multirow{2}{*}{$\begin{array}{l}\text { Total } \\
\text { Protein } \\
\text { Method }\end{array}$} & \multirow{2}{*}{$\begin{array}{l}\text { Electro- } \\
\text { phoretic } \\
\text { Method }\end{array}$} & \multirow{2}{*}{$\begin{array}{l}\text { No. of } \\
\text { Subjects }\end{array}$} & \multirow{2}{*}{$\begin{array}{l}\text { Age of } \\
\text { Subjects } \\
\text { (Years) }\end{array}$} & \multirow{2}{*}{$\left|\begin{array}{c}\text { Total } \\
\text { Protein } \\
(\mathrm{g} . / 100 \mathrm{ml})\end{array}\right|$} & \multirow{2}{*}{$\underset{(\%)}{\text { Albumin }}$} & \multicolumn{4}{|c|}{ Globulin (\%) } \\
\hline & & & & & & & $a_{1}$ & $\alpha_{2}$ & $\beta$ & $\boldsymbol{\gamma}$ \\
\hline Present series .. & \begin{tabular}{|l|} 
Micro-Kjeldahl \\
digestion \\
micro- \\
diffusion
\end{tabular} & $\begin{array}{c}\text { Filter paper } \\
\text { and “,analy- } \\
\text { trol " } \\
\text { densitometer } \\
\text { Tiselius and } \\
\text { planimetry } \\
\text { on Schlieren }\end{array}$ & 30 & $3-19$ & $\begin{array}{l}7 \cdot 20 \pm 0 \cdot 49 \\
(6 \cdot 38-8 \cdot 44)\end{array}$ & ${ }_{\substack{61 \cdot 4^{ \pm} \\
(53 \cdot 2-75}}$ & $\underset{(2 \cdot 7-8 \cdot 8)}{\stackrel{\ddagger}{5 \cdot 2}+1 \cdot 7}$ & $\begin{array}{c}9.5 \pm 1.9 \\
(6.9-13.4)\end{array}$ &  & $\begin{array}{c}12 \cdot 6 \pm 2 \cdot 3 \\
(9 \cdot 0-17 \cdot 5) \\
\\
+ \\
10 \cdot 4 \pm 3 \cdot 9 \\
(4 \cdot 0-18 \cdot 1)\end{array}$ \\
\hline $\begin{array}{l}\text { \$Knapp and } \\
\text { Routh (1949) }\end{array}$ & $\begin{array}{l}\text { Micro-Kjeldahl } \\
\text { digestion } \\
\text { and }\end{array}$ & $\begin{array}{l}\text { diagram } \\
\text { As above }\end{array}$ & 38 & $3-17$ & $\begin{array}{c}7 \cdot 05 \pm 0 \cdot 52 \\
(6 \cdot 1-8 \cdot 3)\end{array}$ & $\mid \begin{array}{c}51 \cdot 9 \stackrel{\ddagger}{ \pm} .4 \cdot 4 \\
(54 \cdot 9-67 \cdot 6)\end{array}$ & $\begin{array}{c}\frac{ \pm}{4} \cdot 0 \cdot 0 \\
(3 \cdot 2-10 \cdot 8)\end{array}$ & $\begin{array}{c}\dagger^{\dagger} \\
(6 \cdot 5-18 \cdot 2 \cdot 0\end{array}$ & $\begin{array}{c}11 \cdot 9 \pm 3 \pm 3 \cdot 3 \\
(5 \cdot 8-17 \cdot 7)\end{array}$ & $\begin{array}{c} \pm \\
9 \cdot 6 \pm 2 \cdot 7 \\
(4 \cdot 8-15 \cdot 6)\end{array}$ \\
\hline $\begin{array}{l}\text { Oberman and } \\
\text { others (1956) }\end{array}$ & $\begin{array}{l}\text { Nesslerization } \\
\text { Biuret }\end{array}$ & $\begin{array}{l}\text { Filter paper } \\
\text { and " analy- } \\
\text { trol " }\end{array}$ & 42 & $3-13$ & $\begin{array}{l}7.25 \pm 0.40 \\
(6.43-8.19)\end{array}$ & $\mid \begin{array}{c}53 \cdot 2 \stackrel{\ddagger}{ \pm} 4 \cdot 9 \\
(41 \cdot 5-65 \cdot 3)\end{array}$ & $\begin{array}{c}\ddagger \\
4 \cdot 9 \pm 1 \cdot 1 \\
(2 \cdot 8-6 \cdot 9)\end{array}$ &  & $\begin{array}{c} \pm \\
13 \cdot 9 \pm 2 \cdot 4 \\
(8 \cdot 6-22 \cdot 4)\end{array}$ & $\begin{array}{c} \pm \\
16 \cdot 3 \pm 3 \cdot 0 \\
(10 \cdot 1-22 \cdot 0)\end{array}$ \\
\hline $\begin{array}{l}\text { Josephson and } \\
\text { Gyllenswärd } \\
\text { (1957) }\end{array}$ & ", & $\begin{array}{l}\text { densitometer } \\
\text { Filter paper } \\
\text { and eluting } \\
\text { cut strip }\end{array}$ & 24 & $3-6$ & $7 \cdot 18 \pm 0 \cdot 57$ & $62 \cdot 1^{\dagger} \pm 4 \cdot 4$ & $5 \cdot 1 \pm \stackrel{\ddagger}{\ddagger} \cdot 2$ & $9 \cdot 8 \pm 2 \cdot 1$ & $9 \cdot 7 \pm 1 \cdot 3$ & $13 \cdot 3 \pm 2 \cdot 1$ \\
\hline
\end{tabular}

* All figures are expressed as the mean plus or minus the standard deviation with the observed range in brackets below. All figures are recalculated to include only data concerning children above the age of 3 years.

+ Differs significantly from the present series at the $5 \%$ level and $\ddagger$ at the $1 \%$ level.

\& Original observations made on plasma, but the figures given are corrected here for the absence of fibrincgen. 
(1948) results in children aged 3 to 11 were treated in a similar manner, but there was no significant correlation $(\mathrm{r}=-0.064)$. A falling alpha 2 globulin with increasing age has also been noted by Oberman and others (1956) and by Josephson and Gyllenswärd (1957). After infancy a rising gamma globulin with age has been reported (Knapp and Routh, 1949; Josephson and Gyllenswärd, 1957) but was not observed in the present series nor by Oberman and others (1956), who found that the adult level was reached between 3 and 5 years.

Comparison of the total serum proteins with other recently published series for normal children (Table II) shows that there is no significant difference between the four results despite the fact that two distinctive methods were used. If the four series are combined, the mean of the 134 cases is $7.17 \mathrm{~g}$. per $100 \mathrm{ml}$. with a standard deviation of 0.48 and an observed range of 6.1 to $8.44 \mathrm{~g}$. per $100 \mathrm{ml}$. serum.

The total serum proteins in this study have been calculated by multiplying the protein nitrogen by the traditional factor of 6.25 in order that the results might be compared with previously published data. Recently, however, Sunderman, Sunderman, Falvo, and Kallick (1958) have suggested that a factor of 6.54 is more appropriate. Recalculation of the results on the 30 cases of cerebral palsy using the larger factor gives a range of 6.68 to 8.83 and a mean of $7.53 \mathrm{~g}$. per $100 \mathrm{ml}$. serum.

Filter paper electrophoresis is a simple technique for demonstrating differences in the pattern of the serum proteins, but it is difficult to estimate the various proteins quantitatively by either scanning or elution techniques. The mean deviations of individual methods are surprisingly low (Grassmann, 1956), so that comparisons of different groups using the same laboratory technique with the same apparatus are justifiable; however, comparison between series is unreliable except in the broadest terms. In Table II, the significant differences at the 5 and $1 \%$ level between the present series and the published series for normal children are marked, but only the proportion of alpha 1 globulin is consistently different at the $1 \%$ level. This fraction is raised in acute infections, particularly within the previous month (Lubschez, 1948). The children used in our series were all under constant medical supervision for at least a month before specimens were collected and were known to be free from any infection during this time. It would be desirable to compare these children with normal children using the same laboratory technique, but it proved impossible to find a group which could be so strictly controlled. The normals tabulated in Table II are thus used for the control group. In view of the above discussion, the difference between the distribution of serum proteins in children with cerebral palsy and normal children is not clinically significant.

The determinations of the protein nitrogen and the alpha amino nitrogen were made by courtesy of Dr. Samuel J. Fomon, of the Department of Pediatrics. The electrophoretic analysis was obtained by the co-operation of Dr. Robert L. Hodges, of the Department of Internal Medicine.

\section{REFERENCES}

Conway, E. J., and O'Malley, E. (1942). Biochem. J., 36, 655. Grassmann, W. (1956). In Ciba Foundation Symposium on Paper Electrophoresis, p. 2. Edited by G. E. W. Wolstenholme and E. C. P. Millar. Churchill, London. Josephson, B., and Gyllenswärd, C. (1957). Scand. J. clin. Lab.
Invest., 9, 29.

Knapp, E. L., and Routh, J. I. (1949). Pediatrics, 4, 508.

Lubschez, R. (1948). Ibid., 2, 570.

Oberman, J. W., Gregory, K. O., Burke, F. G., Ross, S., and Rice, E. C. (1956). New Engl. J. Med., 255, 743 .

Sunderman, F. W., Jr., Sunderman, F. W., Falvo, E. A., and Kallick, C. J. (1958). Amer. J. clin. Path., 30, 112.

Trevorrow, V., Kaser, M., Patterson, J. P., and Hill, R. M. (1942). J. Lab. clin. Med., 27, 471.

Van Slyke, D. D., and Kugel, V. H. (1933). J. biol. Chem., 102, 489.

Yemm, E. W., and Cocking, E. C. (1955). Analyst, 80, 209. 